\title{
INDIVIDUAL DIFFERENCES IN DECISIONS ON PHYSICAL DISTANCING DURING THE COVID-19 PANDEMIC
}

\author{
M.S. ZIRENKO ${ }^{\mathrm{a}}$, T.V. KORNILOVA ${ }^{\mathrm{a}}$
}

${ }^{a}$ Lomonosov Moscow State University, 1 Leninskie Gory, Moscow, 119991, Russian Federation

\begin{abstract}
During the COVID-19 pandemic decisions on physical distancing including decisions on wearing face masks in public may depend on a number of individual characteristics, representations of threats and the degree of personal responsibility for complying with the imposed requirements.. This study on a Russian sample $(\mathrm{N}=308)$ took place during April-May 2020. We used verbal tasks on social distancing to test the hypotheses that individual differences in empathy, implicit theories of emotions, the Dark Triad traits, rationality, and risk readiness predict decisions on whether or not to wear a mask. We developed five verbal tasks - situations where decisions on whether to wear a mask or not were made by choosing from several given reasons. Among the reasons for wearing a mask, Care for Self was chosen by $46 \%$ of participants who received this as a reason, the Law-abidingness reason was chosen by $44 \%$, and $31 \%$ selected Care for Others. Regarding the reasons for not wearing a mask, $16 \%$ of participants chose Autonomy for Oneself, 11\% - Risk Underestimation and 5\% - Autonomy for Others. Logistic regressions identified that empathy, rationality, and narcissism were significant predictors of a decision to wear a face mask, while risk readiness and psychopathy were predictors of a decision not to wear a mask. Implicit theories of emotions and problem-solving self-efficacy were significant predictors only for choices between the reasons for wearing a mask. Personality variables of empathy, rationality, risk readiness, and the Dark Triad traits influence decisions on adhering to physical distancing.
\end{abstract}

Keywords: COVID-19, decision-making, empathy, Dark Triad, risk readiness, rationality, implicit theories of emotions.

\section{Introduction}

The COVID-19 pandemic has raised countless questions about human behavior, decision-making, cooperation, etc. Coronavirus response is viewed as including multiple psychological processes of decision-making on individual and societal levels: threat and risk perception, moral emotions, panic development, compliance with social norms, influence of misinformation, suggestion, empathy, coping with stress, etc. (Bavel et al., 2020). These components could affect decisions to adhere to the new norms to a different degree. The present paper focuses on the individual

This research was supported by the Russian Foundation for Basic Research (Project No. 19-29-07069). 
regulation of decision-making since individual differences and differences in risk representation influence prosocial actions (Zettler et al., 2021).

The decision to wear face masks in public has become one of the requirements of physical distancing during the COVID-19 pandemic. In order to slow the spread of the virus it is crucial to adopt personal protective behaviors (wearing a face mask, disinfecting hands, avoiding touching one's face) in addition to the distancing measures accomplished by closing public spaces and businesses (West et al., 2020). However, decisions on physical distancing include not only consideration of the frequencies of possible outcomes (in this case, chances of getting infected or infecting others). They also involve the influence of risk readiness, empathy and responsibility for oneself and others, which is partially presented in the concept of prosocial orientation in behavior.

However, conscious attitudes to a new threat do not directly lead to behavioral changes that correspond to new requirements. Perception of medical risks is related to their representation in the media (Slovic, 2000) and is affected by differences in individual cognitive representations of risks (Chauvin, 2018). Moreover, it is well-established that in estimating probabilities of possible losses and threats the inclusion of affect removes orientation on the probability of events (Slovic \& Peters, 2006). G. Gigerenzer (2020) emphasizes the importance of improving risk literacy; otherwise our decisions are influenced by the disproportionate "fear of dread risks", which is the case for the fear of coronavirus.

Risk readiness as a personality characteristic presumably could also regulate decision-making on social distancing. Studies on perception of medical risks by doctors identified a number of heuristics that help make optimal decisions in the ecologically valid information representation (Gigerenzer, 2015). The pandemic sheds a new light on the concept of ecological rationality in that it changed the ecological context of risky decision-making.

The problem of the unity of intelligence and emotions has received a new development in the context of the pandemic. Traditionally, emotions and cognitions were conceptualized as opponents (Rothermund \& Koole, 2018). In contrast to these views, the concept of multiple regulation of decisions and actions assumes that cognitive, emotional and personality components of regulation mediate decision-making process simultaneously (Kornilova, 2016). This idea is supported by the integrated neural networks perspective on cognitions and emotions (Pessoa, 2008; etc.).

Emotion regulation of decision-making is studied to a lesser extent than the role of rationality and cognitive processes in decision-making. Studies of framing-effect on the "Asian disease" problem were carried out in cognitive psychology and were discussed within the framework of the dual process theory (System 1 and System 2) (Kahneman, 2011). Later in our studies on medical personnel it was demonstrated that personality variables are related to the decision-making in this task (Bogacheva et al., 2020; Kornilova \& Kerimova, 2018). Although D. Kahneman introduced emotional framing in his last book, identifying the role of emotional components in decision-making as well as their interaction with variables that capture attitude to uncertainty in decision-making is still the problem of the unity of intelligence and affect (Anderson et al., 2019). 
The emotional toll of coronavirus is extremely high (Lima et al., 2020), therefore, beliefs about controllability of emotions (Tamir et al., 2007) might have a positive influence on adapting to the new norms.

Since the emotional response to the virus is intense, we can expect that the Dark Triad personality traits also play an important role in decision-making as they represent an "unstable emotional core". Recent meta-analysis suggests that prosocial behavior in different economic games is associated with higher agreeableness, honesty-humility, social value orientation and lower narcissism and envy (Thielmann et al., 2020). In the current situation of the pandemic those with higher emotionality were more likely to accept the limitations, those with a higher Dark Factor of Personality were less likely to accept them and perceive this pandemic as a risk for their close others, and those with higher neuroticism were more likely to worry about COVID-19 (Zettler et al., 2020; Zettler et al., 2021).

Rationality also plays a role in adhering to new norms. People who performed better on tests that measure willingness to engage in deliberate, reflective process were less likely to think about the pandemic as a deception and more likely to adhere to social-distancing measures and handwashing (Stanley et al., 2020).

A serious health threat highlighted the importance of such an aspect of decision-making as care for self and for others. Philosophical aspects of this issue were developed by M. Foucault and some Russian authors (Ivanchenko, 2009). Decisions related to the risk of contracting the virus and infecting others put this issue in the context of the pandemic. In this vein, it was shown that both trait and situational empathy promotes prosocial intentions (Pfattheicher et al., 2020).

\section{Objective}

The aims of this study are: 1) to identify the main reasons for choosing to wear or not wear a face mask (as a measure of physical distancing) on a Russian sample using verbal tasks that model alternative reasons behind the choice; 2) to examine the influence of individual differences in emotional regulation, the Dark Triad personality traits, risk readiness rationality, etc. on a decision to wear a mask and on reasons behind this decision.

In contrast to social surveys, we designed the study using verbal problems with choices to adhere to physical distancing requirements or not. Verbal tasks were used to identify reasons behind the choice in modeling situations both for everyday and professional decisions (Kornilova, 2016; Sternberg et al., 2000). In this study our goal was to identify the influence of personality characteristics on the choice.

\section{Hypotheses}

1. Personality traits of empathy, rationality, problem-solving self-efficacy and malleable implicit theory of emotions are positive predictors of adhering to physical distancing (wearing a face mask). 
2. Risk readiness and the Dark Triad personality traits - Machiavellianism, narcissism, and psychopathy - are predictors of non-compliance with physical distancing (a choice not to wear a face mask).

3. Various reasons for choice to wear or not wear a face mask can be associated with different personality measures: the reasons Care for Self and Care for Others could be associated with empathy and the Dark Triad personality traits, while Risk Underestimation and Law-abidingness could be associated with rationality, risk readiness and the Dark Triad personality traits.

\section{Methods}

\section{Data Collection Timeline}

We collected data in Russia from April 25th to May 24th 2020 during the period of "self-isolation" together with the requirements for physical distancing and wearing face masks in public areas.

\section{Participants}

308 participants from Russia completed decision-making tasks and questionnaires (259 people participated online and 49 participants filled in questionnaires in a paper-and-pencil format). Participants' age ranged from 18 to 80 y. o. $(\mathrm{M}=32.3$, $\mathrm{SD}=11.71), 80 \%$ female.

\section{Measures}

\section{1) Verbal tasks}

The study was conducted using a quasi-experimental design. All participants received two tasks out of five with different reasons behind the decision to wear or not wear a mask (Task 5 that served as a control). We used the same set of tasks for a cross-cultural study (Zirenko et al., 2021). In different tasks, reasons for wearing or not wearing a mask represented the following categories: Care for Self (CS) vs for Others (CO), Risk for Oneself (RS) vs for Others (RO), Law-abidingness (LA), Personal Autonomy (PA), Autonomy for Others (AO).

Participants completed questionnaires after the verbal tasks.

\section{2) Questionnaires}

All questionnaires were presented in Russian adaptations.

1. Implicit theories of emotions scale (Tamir et al., 2007).

2. Questionnaire of Cognitive and Affective Empathy: perspective taking, online simulation, emotion contagion, proximal responsivity, peripheral responsivity, cognitive empathy, affective empathy, empathy (Reniers et al., 2011).

3. Personality Factors of Decision-making Questionnaire: risk readiness and rationality (Kornilova et al., 2010).

4. The "Dirty Dozen" questionnaire: subclinical narcissism, subclinical psychopathy and Machiavellianism (Kornilova et al., 2015). 
5. The Subjective Risk Intelligence Scale: emotional stress vulnerability, problem solving self-efficacy and imaginative capability (Craparo et al., 2018; Kornilova \& Pavlova, 2020).

\section{Results}

\section{Choice Frequencies}

Choice frequencies were calculated across all the participants and all verbal tasks (see Table 1).

Across all five tasks and 616 choices, among the reasons for wearing a mask Care for Self was chosen by $48 \%$ of participants who received a version of a task with this option, Law-abidingness was chosen by $44 \%$ of participants and Care for Others - by $31 \%$. Regarding the reasons for not wearing a mask, $16 \%$ of participants chose Autonomy for Oneself, and 14\% of participants chose Risk for Oneself.

\section{Framing-effects}

Twelve people out of 308 changed their answers on whether or not they chose to wear a mask when switching from the first task to the second task. Thus, the decisions on physical distancing in tasks that were framed differently, were rarely changed.

\section{Personality Predictors of Choices}

To test whether or not the choice to wear a face mask is mediated by personality characteristics we ran logistic regressions using personality variables as individual predictors. Significant predictors in each of the five tasks are presented in Table 2.

Proximal responsivity emerged as the strongest predictor of a choice to wear a mask in comparison with all other measures. Other subscales of empathy also appeared to be positive predictors: a total score on empathy, cognitive and affective empathy, proximal responsivity, online simulation, and perspective taking.

Rationality and risk readiness, as expected, in opposite ways determined the choice to wear a mask. Among the Dark Triad traits, psychopathy negatively influenced the

Choice Frequencies across All Participants in All Five Tasks

(A1 and A2 - Choices to Wear a Mask, B1 and B2 - Choices Not to Wear a Mask)

\begin{tabular}{|c|c|c|c|c|c|}
\hline \multirow{2}{*}{ Choice } & \multicolumn{5}{|c|}{ Task } \\
\cline { 2 - 6 } & 1 & 2 & 3 & 4 & 5 \\
\hline $\mathrm{A} 1$ & $\mathrm{CS}(56)$ & $\mathrm{CS}(33)$ & $\mathrm{CS}(32)$ & $\mathrm{RS}(22)$ & $\mathrm{CO}(98)$ \\
\hline $\mathrm{A} 2$ & $\mathrm{CO}(27)$ & $\mathrm{CO}(24)$ & $\mathrm{CO}(24)$ & $\mathrm{LA}(23)$ & $\mathrm{LA}(139)$ \\
\hline $\mathrm{B} 1$ & $\mathrm{PA}(24)$ & $\mathrm{RS}(12)$ & $\mathrm{RS}(8)$ & $\mathrm{PA}(9)$ & $\mathrm{PA}(41)$ \\
\hline $\mathrm{B} 2$ & $\mathrm{AO}(2)$ & $\mathrm{RO}(6)$ & $\mathrm{AO}(3)$ & $\mathrm{AO}(3)$ & $\mathrm{RS}(30)$ \\
\hline $\mathrm{N}$ & 109 & 75 & 67 & 57 & 308 \\
\hline
\end{tabular}

Note. $N$ - number of participants who received this task. 
choice to wear a mask in three tasks, while narcissism positively influenced decisions to wear a mask.

Implicit theories of emotions did not appear to be significant predictors in any of the tasks.

Choices in Task 5 where there were four different reasons combined - Care for Others, Law-abidingness, Autonomy for Oneself and Risk Underestimation - were the most affected by personality characteristics.

Next, we analyzed predictors of choices between the reasons to wear a face mask. Malleable beliefs about emotions, perspective taking, cognitive empathy, psychopathy, proximal responsivity, peripheral responsivity, self-efficacy in decision making, imagination, affective empathy, risk readiness, and empathy predicted the choice Care for Others (over Care for Self) in different tasks.

Risk readiness and perspective taking were predictors of choice to Care for Others over Law-abidingness.

Analysis of the choice between two reasons to refuse to wear a mask was carried out only for Task 5 because of the sufficient number of answers collected in this task. No significant personality predictors emerged for the reasons to refuse to wear a mask.

\section{Discussion}

This study has shown that decisions to comply with the requirements of physical distancing are more often made for some reasons rather than for others. Choices

Table 2

Results of Logistic Regressions: Influence of Personality Measures on the Choice in a Verbal Task - to Wear or not Wear a Face Mask

\begin{tabular}{|c|l|c|c|}
\hline Task & \multicolumn{1}{|c|}{ Significant predictors } & B & $\boldsymbol{p}$ \\
\hline \multirow{4}{*}{ Task 1} & Proximal Responsivity & .22 & .03 \\
\cline { 2 - 4 } & Psychopathy & -.13 & .04 \\
\cline { 2 - 4 } & Cognitive Empathy & .09 & .04 \\
\cline { 2 - 4 } & Empathy & .06 & .03 \\
\hline \multirow{3}{*}{ Task 2} & Proximal Responsivity & .34 & .04 \\
\cline { 2 - 4 } & Rationality & .21 & .02 \\
\hline \multirow{5}{*}{ Task 3} & Psychopathy & -.22 & .03 \\
\cline { 2 - 4 } & Narcissism & .21 & .05 \\
\cline { 2 - 4 } & Proximal Responsivity & .19 & .007 \\
\cline { 2 - 4 } & Rationality & .13 & .001 \\
\cline { 2 - 4 } & Online Simulation & .12 & .005 \\
\cline { 2 - 4 } & Psychopathy &. .11 & .005 \\
\cline { 2 - 4 } & Perspective Taking & .08 & .01 \\
\cline { 2 - 4 } & Cognitive Empathy & .08 & .001 \\
\cline { 2 - 4 } & Affective Empathy & -.07 & .008 \\
\cline { 2 - 4 } & Risk readiness & .06 & .001 \\
\cline { 2 - 4 } & Empathy & & \\
\hline
\end{tabular}


to wear a face mask were more often made because of caring for oneself and one's law-abidingness than because of caring for other people. Choices to refuse to wear a mask were more often made because of the focus on autonomy for oneself and less often because of underestimating personal risks.

In part, the bias in reasons that appeared to be most preferred by the participants was associated with the design of the tasks. For instance, the reason of autonomy was not provided for a decision to wear a mask, and the reason of law-abidingness was only related to the decision required by society. At the same time, there is a sufficient individual variability not only in the personal choices for and against compliance with the norms of physical distancing, but also in the reasons behind them.

The framing effect, a change in one's answer on whether to wear or not wear a mask, when presented with different alternatives in two similar tasks, was rarely observed. Apparently, this is because people gave answers about the real situation they were currently in and not about a hypothetical scenario (which usually is the case in studies of framing effects in decision-making). This means the decisions in verbal tasks do not reflect a situational choice, but rather the decisions rooted in their own experience of living during the pandemic.

The influence of personality variables on choice regarding adhering to physical distancing was established for the characteristics of empathy, rationality, risk readiness, and the Dark Triad traits. This could be considered as an argument in favor of the personality rather than situation-determined choice in the verbal tasks.

As we expected in Hypothesis 1, empathy and rationality were found to be predictors of choice as to wearing a mask. Cognitive and affective empathy, as well as the subscale of proximal responsivity that measures response to the emotional state of others, were significant predictors of the choice to wear a mask. This result is consistent with previous studies on the relationship between empathy and prosocial behavior during the pandemic observed in other countries (Pfattheicher et al., 2020).

We did not find evidence that malleable implicit theory of emotions and problem-solving self-efficacy influenced the choice to wear a mask, as we suggested in Hypothesis 1. But these variables influenced the choice of a reason why a person would wear a mask.

As expected in Hypothesis 2, subclinical psychopathy predicted the choice to refuse to wear a mask. This result is consistent with a negative role of a Dark Factor of Personality in accepting and following coronavirus-related measures (Zettler et al., 2020). However, we obtained evidence of the positive influence of narcissism on decisions to wear a mask, which contradicts the hypothesis but is consistent with the conceptualization of narcissism as the "lightest" trait in the Dark Triad (Krasavtseva \& Kornilova, 2019). In addition to psychopathy, risk readiness was also a predictor of the choice not to wear a mask that once again highlights the importance of improving risk assessment literacy (Gigerenzer, 2020).

Regarding Hypothesis 3 on the associations between the personality measures and reasons behind the decisions, there is a trend observed across several tasks - 
higher scores on different facets of empathy positively predict choosing care for others over care for self as a reason to put on a face mask.

\section{Conclusion}

1. Verbal tasks have shown that among the participants who were presented with Care for Self as a reason for wearing a face mask $46 \%$ chose it, while $44 \%$ of those presented with the reason Law-abidingness chose it, and 31\% selected Care for Others. Among those participants who chose not to wear a mask, Autonomy for Oneself was chosen by $16 \%$ of those who were presented with this reason, Risk Underestimation was chosen by $11 \%$ of participants and Autonomy for Others was chosen by $5 \%$ of the participants.

2. Personality variables of empathy, rationality, risk readiness, and the Dark Triad personality traits are significant predictors of decision-making on physical distancing. In particular, rationality, empathy and narcissism are significant predictors of the choice to wear a mask while psychopathy and risk readiness are predictors of the choice to refuse to wear a mask. Implicit theories of emotions and problem-solving self-efficacy do not predict if a person wears a mask or not, but they influence the choice of a reason why a person puts on a mask, or in other words, why he or she demonstrates prosocial behavior.

\section{Limitations}

One of the limitations of this study is that the sample was not balanced by gender - almost $80 \%$ of the participants were women. A study in the U.S. has shown that men are less likely to demonstrate intentions of wearing a mask and less likely to believe they can get infected with coronavirus while they are more likely to think that wearing a mask is a sign of weakness and stigma (Capraro \& Barcelo, 2020). In our study, the sample wasn't balanced by gender; therefore we failed to analyze gender differences.

\section{References}

Anderson, E. C., Carleton, R. N., Diefenbach, M., \& Han, P. K. J. (2019). The relationship between uncertainty and affect. Frontiers in Psychology, 10. Article 2504. https://doi.org/10.3389/ fpsyg.2019.02504

Bavel, J. J. Van, Baicker, K., Boggio, P. S., Capraro, V., Cichocka, A., Cikara, M., Crockett, M. J., Crum, A. J., Douglas, K. M., Druckman, J. N., Drury, J., Dube, O., Ellemers, N., Finkel, E. J., Fowler, J. H., Gelfand, M., Han, Sh., Haslam, S. A., Jetten, J., ... Willer, R. (2020). Using social and behavioural science to support COVID-19 pandemic response. Nature Human Behaviour, 4(5), 460-471. https://doi.org/10.1038/s41562-020-0884-z

Bogacheva, N., Kornilova, T., \& Pavlova, E. (2020). Relationships between medical doctors' personality traits and their professional risk perception. Behavioral Sciences, 10(1), Article 6. https://doi.org/10.3390/bs10010006 
Capraro, V., \& Barcelo, H. (2020). The effect of messaging and gender on intentions to wear a face covering to slow down COVID-19 transmission. arXiv. arXiv:2005.05467

Chauvin, B. (2018). Individual differences in the judgment of risks: Sociodemographic characteristics, cultural orientation, and level of expertise. In M. Raue, E. Lermer, \& B. Streicher (Eds.), Psychological perspectives on risk and risk analysis: Theory, models, and applications (pp. 37-61). Springer. https://doi.org/10.1007/978-3-319-92478-6_2

Craparo, G., Magnano, P., Paolillo, A., \& Costantino, V. (2018). The Subjective Risk Intelligence Scale. The development of a new scale to measure a new construct. Current Psychology, 37(4), 966-981. https://doi.org/10.1007/s12144-017-9673-x

Gigerenzer, G. (2015). Simply rational: Decision making in the real world. Oxford University Press. https://doi.org/10.1093/acprof:oso/9780199390076.001.0001

Gigerenzer, G. (2020, March 15). Why what does not kill us makes us panic. Facts \& Arts. https://www.factsandarts.net/index.php/current-affairs/why-what-does-not-kill-us-makes-us-panic

Ivanchenko, G. V. (2009). Zabota o sebe. Istoriya i sovremennost' [Care for self. History and modernity]. Moscow: Smysl.

Kahneman, D. (2011). Thinking, fast and slow. Farrar, Straus, and Giroux.

Kornilova, T. V. (2016). Intellektual'no-lichnostnyi potentsial cheloveka v usloviyakh neopredelennosti i riska [Intellectual and personal potential of a person under uncertainty and risk]. Saint Petersburg: Nestor-Istoriya.

Kornilova, T. V., Chumakova, M. A., Kornilov, S. A., \& Novikova, M. A. (2010). Psikhologia neopredelennosti: Edinstvo intellektualno-lichnostnogo potentsiala cheloveka [The psychology of uncertainty: The unity of the intellectual and personality potential of a person]. Moscow: Smysl.

Kornilova, T. V., \& Kerimova, S. G. (2018). Specifics of personal prerequisites of decision-making process (based on the framing effect) in doctors and teachers sample groups. Psychology. Journal of the Higher School of Economics, 15(1), 22-38. https://doi.org/10.17323/1813-8918-2018-1-22-38 (in Russian)

Kornilova, T. V., Kornilov, S. A., Chumakova, M. A., \& Talmach, M. S. (2015). The Dark Triad personality traits measure: Approbation of the Dirty Dozen questionnaire. Psikhologicheskii Zhurnal, 36(2), 99-112.

Kornilova, T. V., \& Pavlova, E. M. (2020). Risk Intelligence Scale and its Relationship with Risk Readiness and Emotional Intelligence. Counseling Psychology and Psychotherapy, 28(4), 59-78. https://doi.org/10.17759/ cpp.2020280404 (in Russian)

Lima, C. K. T., Carvalho, P. M. de M., Lima, I. de A. A. S., Nunes, J. V. A. de O., Saraiva, J. S., de Souza, R. I., Lima da Silva C. G., \& Neto, M. L. R. (2020). The emotional impact of Coronavirus 2019$\mathrm{nCoV}$ (new Coronavirus disease). Psychiatry Research, 287, Article 112915. https://doi.org/10.1016/j.psychres.2020.112915

Pessoa, L. (2008). On the relationship between emotion and cognition. Nature Reviews Neuroscience, 9(2), 148-158. https://doi.org/10.1038/nrn2317

Pfattheicher, S., Nockur, L., Böhm, R., \& Sassenrath, C. (2020). The emotional path to action: Empathy promotes physical distancing during the COVID-19 pandemic. PsyArXiv. https://doi.org/10.31234/osf.io/y2cg5

Reniers, R. L. E. P., Corcoran, R., Drake, R., Shryane, N. M., \& Vцllm, В. А. (2011). The QCAE: A Questionnaire of Cognitive and Affective Empathy. Journal of Personality Assessment, 93(1), 8495. https://doi.org/10.1080/00223891.2010.528484 
Rothermund, K., \& Koole, S. L. (2018). Three decades of Cognition \& Emotion: A brief review of past highlights and future prospects. Cognition and Emotion, 32(1), 1-12. https://doi.org/10.1080/02699931.2018.1418197

Slovic, P. (2000). The perception of risk. Routledge. https://doi.org/10.4324/9781315661773

Slovic, P., \& Peters, E. (2006). Risk perception and affect. Current Directions in Psychological Science, 15(6), 322-325. https://doi.org/10.1111/j.1467-8721.2006.00461.x

Stanley, M., Barr, N., Peters, K., \& Seli, P. (2020). Analytic-Thinking Predicts Hoax Beliefs and Helping Behaviors in Response to the COVID-19 Pandemic. PsyArXiv. https://doi.org/ 10.31234/OSF.IO/M3VTH

Sternberg, R. J., Forsythe, G. B., Hedlund, J., Horvath, J. A., Wagner, R. K., Williams, W. M., \& Grigorenko, E. L. (2000). Practical intelligence in everyday life. Cambridge University Press.

Tamir, M., John, O. P., Srivastava, S., \& Gross, J. J. (2007). Implicit theories of emotion: Affective and social outcomes across a major life transition. Journal of Personality and Social Psychology, 92(4), 731-744. https://doi.org/10.1037/0022-3514.92.4.731

Thielmann, I., Spadaro, G., \& Balliet, D. (2020). Personality and prosocial behavior: A theoretical framework and meta-analysis. Psychological Bulletin, 146(1), 30-90. https://doi.org/10.1037/ bul0000217

West, R., Michie, S., Rubin, G. J., \& Amlôt, R. (2020). Applying principles of behaviour change to reduce SARS-CoV-2 transmission. Nature Human Behaviour, 4(5), 451-459. https://doi.org/10.1038/s41562-020-0887-9

Zettler, I., Schild, C., Lau, L., \& Böhm, R. (2020). Individual differences in accepting personal restrictions to fight the COVID-19 pandemic: Results from a Danish adult sample. PsyArXiv. https://doi.org/10.31234/osf.io/pkm2a

Zettler, I., Schild, C., Lilleholt, L., Kroencke, L., Utesch, T., Moshagen, M., Böhm, R., \& Geukes, K. (2021). The role of personality in COVID-19 related perceptions, evaluations, and behaviors: Findings across five samples, nine traits, and 17 criteria. Social Psychological and Personality Science. Advance online publication. https://doi.org/10.1177/19485506211001680

Zirenko, M., Kornilova, T., Qiuqi, Z., \& Izmailova, A. (2021). Personality regulation of decisions on physical distancing: Cross-cultural comparison (Russia, Azerbaijan, China). Personality and Individual Differences, 170, Article 110418. https://doi.org/https://doi.org/10.1016/ j.paid.2020.110418

Maria S. Zirenko - Technician, Faculty of Psychology, Lomonosov Moscow State University. Research Area: implicit theories of intelligence and personality, academic achievement, self-regulation.

E-mail: mzirenko@inbox.ru

Tatiana V. Kornilova - Professor, Department of Psychology, Lomonosov Moscow State University, DSc in Psychology.

Research Area: psychology of thinking and decision-making, psychology of personality, psychology of risk, self regulation, intellectual-personality potential.

E-mail: tvkornilova@mail.ru 


\title{
Индивидуальные различия в решениях о физическом дистанцировании во время пандемии COVID-19
}

\author{
М.С. Зиренко ${ }^{\mathrm{a}}$, Т.В. Корнилова ${ }^{\mathrm{a}}$ \\ ${ }^{a}$ Московский государственныгй университет имени М.В. Ломоносова, 119991, Россия, Москва, \\ Ленинские горы, 1
}

\section{Резюме}

В условиях регулирования социального дистанцирования при эпидемии COVID-19 решения надевать или не надевать маску могут зависеть от ряда индивидуальных представлений об угрозе и степени личной ответственности за выполнение заданных требований. В исследовании на российской выборке ( $\mathrm{N}=308)$ проверялись гипотезы о том, что индивидуальные различия в свойствах эмпатии, имплицитных теорий эмоций, Темной триады, рациональности и готовности к риску выступят предикторами решений надевать или не надевать маску в вербально заданных ситуациях (в условиях требования социального дистанцирования). Было разработано пять ситуаций, выходы из которых включали решения надевать маску или нет в общественных местах, но на разных основаниях. Анализировались частоты выборов и интеркорреляции личностных свойств, которые рассматривались как предикторы при применении логистической регрессии. В качестве оснований «надеть маску» заботу о себе выбирали 46\% из тех, кому был доступен этот ответ, законопослушность - 44\%, заботу о других - 31\%. В качестве оснований отказа от маски автономию для себя выбирали $16 \%$, восприятие риска как низкого - $11 \%$, автономию для других - 5\%. Применение логистической регрессии позволило установить, что предикторами положительных решений выступили эмпатия, рациональность и нарциссизм, а предикторами решения не надевать маску - готовность к риску и субклиническая психопатия. Имплицитные теории о возможности управлять эмоциями, а также самоэффективность при принятии решений стали значимыми предикторами только при выборе между основаниями носить маску. Личностные свойства эмпатии, рациональности, готовности к риску и Темной триады влияют на решения придерживаться физического дистанцирования.

Ключевые слова: COVID-19, принятие решений, эмпатия, Темная триада, готовность к риску, рациональность, имплицитные теории эмоций.

Зиренко Мария Сергеевна - инженер, факультет психологии, Московский государственный университет имени М.В. Ломоносова.

Сфера научных интересов: имплицитные теории интеллекта и личности, академическая успешность, саморегуляция.

Контакты: mzirenko@inbox.ru

Корнилова Татьяна Васильевна - профессор, факультет психологии, Московский государственный университет имени М.В. Ломоносова, доктор психологических наук.

Сфера научных интересов: психология мышления и принятия решений, психология личности, психология риска, саморегуляция, интеллектуально-личностный потенциал.

Контакты: tvkornilova@mail.ru 